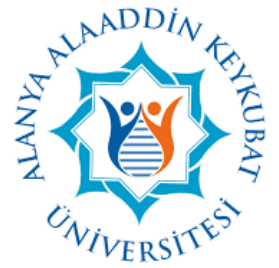

\title{
Doğaltaş Üretim ve İşleme Tesisi Atıklarının Değerlendirilmesi
}

\author{
Gökhan AYDIN ${ }^{1}$, İzzet KARAKURT ${ }^{\mathbf{1}^{*}}$ \\ ${ }^{I}$ Karadeniz Teknik Üniversitesi, Mühendislik Fakültesi, Maden Mühendisliği Bölümü, Trabzon, Türkiye \\ *karakurt@ktu.edu.tr
}

\begin{abstract}
Özet
Doğal taşlar, sahip oldukları önemli özellikleri sayesinde başta inşaat sektörü olmak üzere çeşitli alanlarda yapı malzemesi olarak kullanılmaktadır. Ancak, bu ürünlerin üretiminin/işlenmesinin çeşitli aşamalarında yüksek miktarlarda atık açığa çıkmaktadır. Bu atıklar topografya değişikliliği, yüzey/yeraltı sularında bozulma ve hava/görüntü kirliliği gibi çevresel problemlere yol açmaktadır. Üretimin/işlenmenin farklı aşamalarında açığa çıkan bu atıklar; yapı malzemesi ve beton üretiminde, yol yapımında, dolgu ve cam endüstrisinde ve taşkın önleme barikatlarının oluşturulmasında, toprağın nötralizasyonunda, çimento üretiminde, malzeme üretiminde, filtreleme işlemlerinde, plastik üretiminde, boya ve yem endüstrisinde gibi bazı diğer uygulamalarda değerlendirilebilmektedir. Ayrıca; granit gibi sert doğaltaş atıkları, aşındırıcılı sujeti ile kayaç kesmede veya doğal taşların aşındırma prosesleri gibi uygulamalarda aşındırıcı malzeme olarak da kullanılabilmektedir. Bu çalışmada, doğaltaş atıklarının endüstrinin farklı alanlarındaki kullanım seçeneklerine yönelik bir değerlendirme sunulmuştur. Doğaltaş atıklarının çalışmada da bahsedilen farklı alanlarda etkin değerlendirilmesi ile ciddi bir çevresel problemin önüne geçilmiş olacaktır. Ek olarak, bu atıklardan gelir elde edileceğinden doğaltaş işletmecilerine ve ülke ekonomisine önemli katkılar sunulacaktır.
\end{abstract}

Anahtar Kelimeler: Doğaltaş, Atık, Kullanım, Ekonomi.

\section{Evaluation of Natural Stone Production and Processing Plant Wastes}

\begin{abstract}
Thanks to their important properties, natural stones are used as building materials in various fields, especially in the construction sector. However, high amounts of waste are generated at various stages of the production/processing of these products. These wastes result in environmental problems such as topography change, surface/groundwater degradation and air/visual pollution. These wastes generated at different stages of production/processing; can be used in building materials and concrete production, road construction, filler and glass industry and some other applications such as in flood prevention barricades, neutralization of soil, cement production, material production, filtering processes, plastic production, paint and feed industry. Hard natural stone wastes such as granite can also be used as an abrasive material in rock cutting with abrasive waterjet or in etching processes of natural stones. In this study, an evaluation of the usage options of natural stone wastes in different areas of the industry is presented. A serious environmental problem will be prevented by the effective evaluation of natural stone wastes in different areas mentioned in the study. In addition; since there will be income from these wastes, significant contributions will be offered to natural stone operators and the national economy.
\end{abstract}

Keywords: Natural stone, Waste, Usage, Economy. 


\section{GíRiş}

Ticari olarak işletilebilen en eski inşaat malzemeleri doğal taşlardır. Sahip oldukları özellikler sayesinde (desenli, dayanıklı olmaları vb.), tarih boyunca çeşitli alanlarda yapı malzemesi olarak kullanılmışlardır [1,2]. Günümüzde ise özellikle inşaat sektöründe ve diğer bazı alanlarda (heykel, mezar taşı, süs eşyası yapımı vd.) yaygın olarak kullanılmaktadır. Bu nedenle doğaltaş sektörü, hem dünya hem de Türkiye ticareti açısından büyük önem arz eden bir sektör haline gelmiştir [3-5]. Tablo 1'de sunulan dünya doğaltaş ihracatı güncel verileri, bu önemi daha da ön plana çıkarmaktadır. Tablo 1 incelendiğinde, 2019 yılı dünya toplam doğaltaş ihracat1 16 milyar doları aştığı görülmektedir. Bu miktara en büyük katkıyı yapan ilk iki ülke sırasıyla \% 19,84 ile Çin ve \% 13,12 ile İtalya'dır. Ayrıca, sektörün büyüklügünü dünya doğaltaş ithalat verileri de yansıtmaktadır. Bir başka deyişle, 2019'da dünya doğaltaş ithalatı yaklaşı 16 milyar dolar olarak gerçekleşmiştir (Tablo 2). Bu verilere en büyük katkıyı yapan ilk iki ülke sırasıyla \% 18,36 ile Amerika Birleşik Devletleri ve \% 16,62 ile Çin olmuştur. Burada Çin'in, dünya doğaltaş ihracatı ve ithalatında söz sahibi ve etkin bir ülke konumda olduğu açıkça görülmektedir.

Tablo 1. Dünya doğaltaş ihracatı $\left(10^{3}\right.$ ABD \$) [6]

\begin{tabular}{lrrrc}
\hline Ülkeler & $\mathbf{2 0 1 7}$ & $\mathbf{2 0 1 8}$ & $\mathbf{2 0 1 9}$ & $\mathbf{2 0 1 9}$ Pay (\%) \\
\hline Çin & 3.257 .441 & 3.415 .574 & 3.236 .882 & 19,84 \\
\hline İtalya & 2.996 .887 & 2.292 .874 & 2.141 .242 & 13,12 \\
\hline Hindistan & 790.910 & 805.636 & 875.286 & 5,36 \\
\hline Türkiye & 861.387 & 697.226 & 620.524 & 3,80 \\
\hline Brezilya & 659.419 & 644.920 & 607.961 & 3,73 \\
\hline İspanya & 752.091 & 612.632 & 552.198 & 3,38 \\
\hline Portekiz & 567.651 & 481.686 & 470.083 & 2,88 \\
\hline Yunanistan & 100.941 & 92.341 & 425.850 & 2,61 \\
\hline Misir & 414.959 & 507.060 & 415.900 & 2,55 \\
\hline Vietnam & 515.902 & 453.668 & 414.530 & 2,54 \\
\hline Dünya & $\mathbf{1 7 . 6 5 5 . 6 2 9}$ & $\mathbf{1 7 . 7 5 4 . 3 0 0}$ & $\mathbf{1 6 . 3 1 7 . 2 9 7}$ & $\mathbf{1 0 0}$ \\
\hline
\end{tabular}

Alp-Himalaya kuşağı içinde kalan Portekiz, İspanya, İtalya, Yunanistan, Türkiye, İran, Pakistan gibi ülkelerin karbonatlı kayaç (mermer, kireçtaşı, traverten ve oniks) rezervleri oldukça yüksektir. İspanya, Norveç, Finlandiya, Ukrayna, Rusya, Pakistan, Hindistan, Çin, Brezilya ve Güney Afrika'da ise fazla miktarlarda magmatik kayaç rezervleri bulunmaktadır. Asya kıtasında başta Çin olmak üzere, Hindistan ve İran önemli üretim potansiyeline sahiptir. Avrupa kıtasında ise İtalya, İspanya, Türkiye ve Portekiz doğaltaş üretiminde ve ticaretinde söz sahibi ülkeler arasındadır [6]. Son yıllarda üretim ve işleme teknolojilerindeki gelişmelerle birlikte küresel doğaltaş üretimi de artış göstermiştir [7-8]. Giderek daha mükemmel hale getirilen işleme teknikleri ile doğal taşlar, kolay ve ekonomik olarak istenen şekilde işlenmekte ve yeni kullanım alanları bulmaktadır.

Türkiye, 5,1 milyar $\mathrm{m}^{3}$ (13,9 milyar ton) muhtemel mermer rezervine sahiptir. Bu değer dünya rezerv toplamının (15 milyar $\mathrm{m}^{3}$ ) yaklaşık \%33'üne karşılık gelmektedir. Türkiye'nin uluslararası piyasada en tanınmış mermer çeşitleri; Süpren, Elazığ Vişne, Akşehir Siyah, Manyas Beyaz, Bilecik Bej, Kaplan Postu, Denizli Traverten, Ege Bordo, Milas Leylak, Gemlik Diyabaz ve Afyon Şeker'dir. Bunların dışında, son dönemde kayrak taşı, çakıl taşları ve tüfler de dış ticarette öne çıkmaktadır. Türk doğaltaş sektörü; çeşit ve rezerv zenginliği, sektör deneyimi, ham madde bolluğu, deniz ulaşımında nakliye kolaylığı, dinamik sektör yapısı, kullanılan yeni teknolojiler ve geniş renk skalası ile dünya doğal taş piyasasında önemli bir yere sahiptir. Türkiye'de başlica kristalin kalker (mermer), kalker, oniks, konglomera, breş ve magmatik kökenli kayaçlar (granit, siyenit, diyabaz, diyorit, serpantin, vb.) bulunmaktadır [9]. Rezervler, Anadolu ve Trakya boyunca geniş bir bölgeye yayılmıştır (Ege \%32, Marmara \%26, İç Anadolu \% 11 ve diğer bazı bölgeler (Doğu Anadolu, Güneydoğu Anadolu, Karadeniz ve Akdeniz) \%31). Yaklaşık 1.500 adet doğaltaş ocağ1, 2.000 fabrika, 9.000 orta ve küçük ölçekli atölye sektörde faaliyet göstermektedir. Bu faaliyetlerde istihdam edilen kişi sayısı ise 300.000 civarındadır. Balıkesir, Afyon, Bilecik, Denizli ve Muğla toplam doğaltaş 
üretiminin \%65'ini gerçekleştirmektedir. Ekonomik mermer yataklarının bulunduğu diğer iller ise; Bursa, Kırşehir, Çankırı, Çorum, Kastamonu, Niğde, Kayseri, Artvin, Bitlis, Erzincan, Bayburt, Sivas, Tokat, Denizli, Kütahya, Eskişehir, Diyarbakır, Elazığ, Çanakkale, Konya, İstanbul ve Manisa'dır [6,10]. Özellikle son dönemde işlenmiş mermer üretimindeki büyük artış sayesinde Türkiye ekonomisine önemli katkılar sağlanmaktadır. İşlenmiş mermer üretimindeki artışa imkân sağlayan etmenler aşağıdaki gibi sıralanabilir:

- Nitelikli işgücü ve ileri teknolojiye dayanan modern üretim yöntemlerinin kullanılmaya başlanması

- Büyük firmaların yapmış oldukları yatırımlar

- Bütünleşmiş üretim yapan tesislerin devreye alınması.

Tablo 2. Dünya doğaltaş ithalatı $\left(10^{3} \mathrm{ABD} \$\right)[6]$

\begin{tabular}{lrrrc}
\hline Ülkeler & $\mathbf{2 0 1 7}$ & $\mathbf{2 0 1 8}$ & $\mathbf{2 0 1 9}$ & $\mathbf{2 0 1 9}$ Pay (\%) \\
\hline ABD & 3.243 .693 & 3.190 .908 & 2.915 .082 & 18,36 \\
\hline Çin & 2.750 .530 & 2.617 .185 & 2.638 .006 & 16,62 \\
\hline Güney Kore & 950.153 & 977.283 & 802.025 & 5,05 \\
\hline İngiltere & 661.761 & 680.355 & 700.854 & 4,41 \\
\hline Japonya & 580.981 & 584.915 & 587.421 & 3,70 \\
\hline Fransa & 509.193 & 561.213 & 570.633 & 3,59 \\
\hline Almanya & 578.908 & 593.771 & 552.409 & 3,48 \\
\hline Vietnam & 129.605 & 136.970 & 435.893 & 2,75 \\
\hline İtalya & 397.665 & 370.065 & 376.339 & 2,37 \\
\hline Suudi Arabistan & 333.363 & 340.320 & 358.607 & 2,26 \\
\hline Dünya & $\mathbf{1 7 . 4 4 8 . 9 5 7}$ & $\mathbf{1 7 . 0 5 4 . 8 2 9}$ & $\mathbf{1 5 . 8 7 5 . 6 5 0}$ & $\mathbf{1 0 0 , 0 0}$ \\
\hline
\end{tabular}

Türkiye dünya doğaltaş üretiminde lider ülkelerden biridir [11]. Üretimin tamamına yakın kısmı özel sektör tarafından yapılmaktadır [10]. Yıllık doğaltaş üretimi yaklaşık 11,5 milyon ton olup işleme tesislerinin toplam plaka üretim kapasitesi 6,5 milyon $\mathrm{m}^{2}$ civarındadır. Türkiye'nin doğaltaş sektöründeki 2019 yılsonu ihracat verilerine bakıldığında, Çin'in \%37,3'lük pay ile ilk sırada yer aldığı söylenebilir (Tablo 3). Bu dönemde Çin'e yapılan ihracat, önceki yıla göre \%10,22 gibi bir düşüş ile yaklaşık 694 milyon ABD Doları civarında gerçekleşmiş̧ir. Doğaltaş sektöründe 2019 yılında yalnızca Çin'e olan ihracatta değil, sektörün toplam ihracatında da yaklaşık \% 2,3'lük bir düşüş gerçekleşmiştir. Sektör ihracatı, 2018 yılı için 1,9 milyar ABD Doları seviyesindeyken 2019 yılı sonunda 1,86 milyar ABD Doları seviyesine gerilemiştir.

Tablo 3. Türkiye'nin doğaltaş ihracatının ülkelere göre dağılımı (106 ABD \$) [6]

\begin{tabular}{lcccc}
\hline Ülkeler & $\mathbf{2 0 1 8}$ & $\mathbf{2 0 1 9}$ & $\begin{array}{c}\mathbf{2 0 1 9} \text { Pay } \\
\mathbf{( \% )}\end{array}$ & $\begin{array}{c}\mathbf{2 0 1 8 - 2 0 1 9} \\
\text { Değişim }(\mathbf{\%})\end{array}$ \\
\hline Çin & 773 & 694 & 37,33 & $-10,22$ \\
\hline ABD & 299 & 285 & 15,33 & $-4,68$ \\
\hline Suudi Arabistan & 105 & 125 & 6,72 & 19,05 \\
\hline Hindistan & 90 & 91 & 1,11 & 4,90 \\
\hline İsrail & 60 & 65 & 3,50 & 8,33 \\
\hline Irak & 62 & 64 & 3,44 & 3,23 \\
\hline Fransa & 55 & 62 & 3,34 & 12,73 \\
\hline BAE & 54 & 40 & 2,15 & $-25,93$ \\
\hline Avustralya & 40 & 40 & 2,15 & 0,00 \\
\hline Almanya & 27 & 27 & 1,45 & 0,00 \\
\hline İlk on ülke toplam1 & 1565 & 1493 & 80,31 & $-4,60$ \\
\hline Toplam & $\mathbf{1 9 0 3}$ & $\mathbf{1 8 5 9}$ & $\mathbf{1 0 0 , 0 0}$ & $\mathbf{- 2 , 3 1}$ \\
\hline
\end{tabular}

Türkiye'nin doğaltaş sektöründeki 2019 yılsonu ithalat verilerine bakıldığında ise Hindistan'ın yaklaşık \%35'lik pay ile ilk sırada yer aldığı görülmektedir. Hindistan'ı \%16,9 oranında payı ile İtalya ve \%11,3 
payla Vietnam takip etmektedir. Doğaltaş sektörünün ihracatında 2019 yılında yaşanan düşüş, sektörün ithalatında da söz konusudur ve toplamda yaklaşık \% 24 oranında bir azalış gerçekleşmiş̧tir (Tablo 4).

Tablo 4. Türkiye'nin doğaltaş ithalatının ülkelere göre dağılımı (106 ABD \$) [6]

\begin{tabular}{lcccc}
\hline Ülkeler & $\mathbf{2 0 1 8}$ & $\mathbf{2 0 1 9}$ & $\begin{array}{c}\mathbf{2 0 1 9} \text { Pay } \\
(\mathbf{\%})\end{array}$ & $\begin{array}{c}\mathbf{2 0 1 8 - 2 0 1 9} \\
\text { Değişim }(\boldsymbol{\%})\end{array}$ \\
\hline Hindistan & 41,3 & 21,6 & 34,76 & $-33,17$ \\
\hline İtalya & 10,2 & 13,4 & 16,88 & 31,37 \\
\hline Vietnam & 13,8 & 9 & 11,34 & $-34,78$ \\
\hline İspanya & 13,2 & 8,5 & 10,71 & $-35,61$ \\
\hline Yunanistan & 5,3 & 5,8 & 7,30 & 9,43 \\
\hline İran & 8,9 & 5,4 & 6,80 & $-39,33$ \\
\hline Çin & 4,7 & 4,4 & 5,54 & $-6,38$ \\
\hline Makedonya & 0,7 & 1,2 & 1,51 & 71,43 \\
\hline Fransa & 1,0 & 1,0 & 1,26 & 0,00 \\
\hline Portekiz & 0,2 & 0,4 & 0,50 & 100 \\
\hline İlk on ülke toplamı & 99,3 & 76,7 & 96,60 & $-22,76$ \\
\hline Toplam & $\mathbf{1 0 5}$ & $\mathbf{7 9 , 4}$ & $\mathbf{1 0 0 , 0 0}$ & $\mathbf{- 2 4 , 4}$ \\
\hline
\end{tabular}

Türkiye'nin doğaltaş sektöründeki ihracat ürün çeşidine bakıldığında, blok ve işlenmiş mermerin, 2019 yılı ihracatının sırasıyla yaklaşık 853 milyon ve 932 milyon ABD Doları ile ilk siralarda yer aldığı görülmektedir. Mermer haricinde ise Türkiye'nin doğaltaş sektöründeki diğer önemli ihraç ürünleri, blok ve işlenmiş granittir. Sektördeki ithalat ürün çeşitliliğinde ise ihracat çeşitliliğinin tam aksine işlenmiş granitin 2019 yılı ithalatının yaklaşık 47 milyon ABD Doları ile ilk sırada yer aldığı görülmektedir (Tablo 5) $[6]$.

Tablo 5. Ürünler bazında Türkiye'nin doğaltaş ihracat ve ithalat değerleri [6]

\begin{tabular}{|c|c|c|c|c|}
\hline \multirow{2}{*}{ Ürün Tipi } & \multicolumn{2}{|c|}{ İhracat $\left(10^{3}\right.$ ABD \$) } & \multicolumn{2}{|c|}{ İthalat $\left(10^{3} \mathrm{ABD} \$\right)$} \\
\hline & 2018 & 2019 & 2018 & 2019 \\
\hline Blok mermer & 936.498 & 852.837 & 2.861 & 4.405 \\
\hline Blok granit & 6.635 & 9.297 & 373 & 367 \\
\hline İşlenmiş mermer & 906.562 & 931.533 & 20.367 & 23.600 \\
\hline İşlenmiş granit & 9.064 & 10.561 & 75.598 & 46.823 \\
\hline Diğerleri & 44.554 & 55.148 & 5.765 & 4.205 \\
\hline Toplam & 1.903.313 & 1.859.376 & 104.964 & 79.400 \\
\hline
\end{tabular}

\section{DOĞAL TAŞLAR VE DOĞALTAŞ İşLETMECİLİĞi}

Kayaçlar, bir veya daha fazla mineralin bir araya toplanmasıyla oluşan mineral topluluklarıdır. Oluşum şartlarına ve kökenlerine göre magmatik, tortul ve başkalaşım olmak üzere başlıca üç gruba ayrılmaktadırlar $[12,13]$.

Magmatik kayaçlar ergimiş halde bir silikat hamuru olan magmanın veya akkorun yerkabuğunun derinliklerinde ya da yeryüzünde soğuyarak katılaşması sonucu oluşan kayaçlardır. Diğer bütün taşların kökenini oluştururlar. Oluşum derinliklerine göre; plütonik, damar ve volkanik kayaçlar olmak üzere üç gruba ayrılırlar. Magmanın soğuması ve katılaşması derinlerde meydana gelirse ortaya çıkan kayaçlara plütonik (derinlik kayaçları-örneğin granit) kayaçlar denir. Magmanın soğuma ve katılaşması yüzeyde meydana gelirse ortaya çıkan kayaçlara volkanik kayaçlar (bazalt) denir. Ayrıca, magmanın derinlerden yeryüzüne doğru yükselirken yeryüzüne yakın kesimlerde soğumasıyla oluşan kayaçlar da yarı derinlik (damar) kayaçları olarak adlandırılırlar. Magmatik kayaçlar, kristalli (taneli), tabakalanmasız ve kütleler halindedirler. İçlerinde fosil bulunmaz ve asitten etkilenmezler. 
Tortul kayaçlar daha önce oluşmuş kayaçların parçalanması, taşınması, çökelme ortamlarında biriktirilmesi ve taşlaşmasıyla oluşabildiği gibi, geçmişte yaşamış organizma parçalarından da oluşabilir. Bu kayaç grubu genellikle tabakalı bir yapıya sahiptir. Çökeldikleri ortamlar temelinde kimyasal, kırıntılı ve organik tortul kayaçlar olarak sınıflandırılırlar. Kimyasal tortul kayaçlar (traverten, kaya tuzu, kireç taşı, dolomit vd.), kayaçların su ve nemin etkisiyle çözünmesi ve bu çözeltinin çökelmesiyle meydana gelirler. Kırıntılı tortul kayaçlar (breş, konglomera, kumtaşı, kil, marn, vd.), yeryüzündeki kayaçlardan çevresel etkilerle (akarsu, rüzgâr, buzul ve dalgaların) koparılan parçaların çukur yerlerde birikmesi ve doğal bir çimento ile yapışması sonucu oluşur. Organik tortul taşlar (mercan kalkeri, turba, linyit, taş kömürü, antrasit, tebeşir vd.) canlı kalıntılarının çökelerek birikmesi ve zamanla sıkışmasıyla meydana gelir. Tortul kayaçlar, tabakalı ve kristalsiz bir yapıdadır. Oluştukları zamana ait canlı kalıntıları (fosiller) içerirler ve asitten etkilenirler.

Başkalaşım (Metamorfik) kayaçları, var olan kayaçların yüksek sıcaklık ve basınç altında basınç ve sıcaklık etkisiyle değişime uğrayarak yeniden kristalleşmesi ile oluşan kayaçlardır. Basınç ve sıcaklığın etkisiyle kayaçların fiziksel ve kimyasal yapıları değişir. Bu kayaçlar (gnays, mikaşist, talkşist, kloritşist, serpantinit, kuvarsit, mermer vd.) genellikle kristalli yapıya sahiptirler ve metamorfizmaya özgü yeni mineral içerirler $[12,14]$.

Ticari standartlara uygun boyutlarda blok verebilen, kesilip parlatılan/yüzeyi işlenebilen ve malzeme özellikleri kaplama taşı normlarına uygun olan her türden kayaç (tortul, magmatik ve metamorfik) ticari dilde "mermer" olarak bilinmektedir. Bu tanım uyarınca granit, siyenit, serpantin, andezit, bazalt gibi magmatik; kalker, traverten, kumtaş1 gibi tortul; gnays, mermer, kuvarsit gibi metamorfik taşlar mermer olarak isimlendirilmektedir [15]. Doğal taşlar geçmişten günümüze barınak, mezar ve putların, savaş ve av gereci olarak kullanılan baltaların, tarım aletlerin (mahsulleri öğütmek için değirmenlerde vd.) yapımlarında, ticari ve sosyal hayatta iletişim aracı olarak (taş yazıtlar, kitabeler vd.), deri işlemeciliğinde, boya üretiminde ve takılarda, tiyatro, yol, köprü, hamam, kütüphane, ibadethane, anıt, çeşme ve kervansaraylarda, inşaat, kaplama, döşeme, süsleme ve heykelcilik gibi alanlarda kullanılmışlardır [16,17].

Doğaltaş yatakları farklı topoğrafik koşullarda olabilmektedir. Ova tipi yataklar, genellikle topoğrafik seviyenin altındadırlar. Dolayısıyla, yağışlardan kaynaklanan sular üretim bölgelerinde birikerek üretim verimliliğini ve maliyetini olumsuz yönde etkilemektedir. Kesilerek çıkarılan doğaltaş blokları vinçler ya da rampalar yardımıyla ocak dışına alınmaktadır. Yamaç-tepe tipi yataklar ise dağların/tepelerin veya vadilerin yamaçlarında/tepelerinde yer alırlar. Bu yatakların işletilmesinde su önemli bir sorun teşkil etmemektedir. Ancak, uzun ulaşım yollarına ihtiyaç duyulması maliyeti arttıran bir özellik olarak ön plana çıkmaktadır. Ayrıca, doğaltaş yatağının yükseltisi-dalımı ve çevresel koşullar problem yaratabilmektedir (kar yăğşları vb.) [18]. Farklı tip yataklarda uygulanan yöntemler arasında geçişlerin yapılabilmesi mümkündür. Yamaç-tepe tipi bir ocak üretim sonucu ova tipi bir ocağa dönüşebilir.

Doğaltaş üretiminde, delme çatlatma, elmas telle kesme, zincirli kollu kesicilerle kesme ve bu yöntemlerin çeşitli kombinasyonlarını içeren yöntemler kullanılmaktadır (Tablo 6) [19]. Bu yöntemlerden bağımsız olarak doğaltaş üretimi, belli faaliyetlerin organizasyonu ile gerçekleştirilir. Bu faaliyetlere ilişkin bilgiler Tablo 7'de verilmiştir.

\section{DOĞALTAŞ ATIKLARI}

Ocaklarda ve fabrikalarda yürütülen kesme faaliyetlerine bağlı olarak üretimin \% 40-70'i oranında doğaltaş atığı ortaya çıkmaktadır [20-22]. Atık miktarı doğal taşın mineralojisine, süreksizlik ve çatlak yapısına, üretim ve işleme faaliyetlerine bağlı olarak farklılıklar göstermektedir [14,23,24]. Doğaltaş fabrikalarında oluşan atıklar, boyutlarına göre iri ve ince olmak üzere iki şekilde sınıflandırılabilirler. İri boyutlu atıklar, ocaktaki üretimin yaklaşık \%40'ını oluştururlar ve boyutları birkaç $\mathrm{cm}$ den birkaç metreye kadar değişebilen atıklardır. Bu atıklar, farklı şekillerde olabilmektedirler (Şekil 1). Fabrikalarda işlenen doğal taşların yaklaşık \%30'una denk gelen ince boyutlu atıklar ise çoğunlukla toz boyutundadır (150 $\mu$ m'nin altında) (Şekil 2). Bu atıklar yükleyicilerle kamyonlara yüklenmekte ve pasa döküm sahalarına nakledilmektedir. Doğaltaş işletme sahası ve doğaltaş yataklarından uzak bölgelerdeki boş tarım arazileri 
depo alanı olarak kullanılmaktadır. Halbuki, tarım arazilerinin daha etkin şekilde kullanılması ve korunması gerekirken boş olsa dahi tarım dışı kullanımlar için işgal edilmemesi ve tarıma elverişli olmayan arazilerin bu amaçlar için değerlendirme şeklinin tespitine yönelik işlemlerin yapılması gerekir. İşletme sahasının depo alanı olarak kullanılması durumunda da sahadaki manevra kabiliyeti azalmaktadır [25,26]. Atıkların başka bir alanda depolanması durumunda ise nakliyeden ötürü ek maliyetler söz konusu olmaktadır [27]. Doğaltaş atıkları, topografya değişikliliği, toprak işgali, yüzey/yeraltı sularında bozulma, hava ve görüntü kirliliği gibi çevresel etkilere de sebep olabilmektedirler $[22,28,29]$.

Tablo 6. Doğaltaş üretim yöntemleri [19]

\begin{tabular}{|c|c|}
\hline Üretim yöntemi & Özellik \\
\hline Delme çatlatma & $\begin{array}{l}\text { Kesim yapılacak doğrultuda sıralı delikler açılır. Bu deliklere mermer çivisi ve } \\
\text { yapraklar sıkıştırılarak bloğun çatlaması sağlanır. Her türlü formasyonda düşük } \\
\text { yatırımlarla uygulanabilen bir yöntemdir. Ancak, üretim hızı düşüktür ve malzeme } \\
\text { kayıp oranları yüksektir. İlk yatırım maliyenin düşük olmasından ötürü daha çok arama } \\
\text { çalıșmalarında veya çok sert kayaçların üretilmesinde kullanılmaktadır. }\end{array}$ \\
\hline Elmas telle kesme & $\begin{array}{l}\text { Birbiriyle birleşen üç delik açılır ve bu deliklerden elmas tel geçirilir. Telin } \\
\text { döndürülmesi ve geri çekilmesi sonucunda kesim işlemi gerçekleşir. }\end{array}$ \\
\hline $\begin{array}{l}\text { Zincirli kollu } \\
\text { kesicilerle kesme }\end{array}$ & $\begin{array}{l}\text { Ray üzerine yerleştirilmiş kollu kesicinin kesme düzlemi boyunca hareket } \\
\text { ettirilmesiyle kesme gerçekleşir. }\end{array}$ \\
\hline $\begin{array}{l}\text { Yöntemlerin } \\
\text { kombinasyonu }\end{array}$ & $\begin{array}{l}\text { Yukarıda belirtilen yöntemler birlikte de uygulanabilmektedir. Örneğin çalışmanın } \\
\text { daha zor olduğu alt kesimlerde kollu kesiciler, arka ve profil kesimlerinde ise basamak } \\
\text { yüksekliklerinden dolayı elmas tel kullanılabilir. }\end{array}$ \\
\hline
\end{tabular}

Tablo 7. Doğaltaş üretim aşamaları [19,30,31]

\begin{tabular}{ll}
\hline Aşama & \multicolumn{1}{c}{ Açılama } \\
\hline Planlama & Uygulanacak teknoloji ve kullanılacak donanım belirlenmektedir. \\
Hazırlık & $\begin{array}{l}\text { Çalışma alanının temizlenmesi, delme/kesme parametrelerinin belirlenmesi, deliklerin } \\
\text { açlması (delme çatlatma ve elmas telle kesme yöntemlerinde) ve rayların yere } \\
\text { sabitlenmesi (zincirli kollu kesicilerle kesme yönteminde) gibi faaliyetler yapılır. }\end{array}$ \\
\hline Kesme & Bkz. Tablo 4 \\
\hline Ayırma & $\begin{array}{l}\text { Kesme işlemi tamamlanan kütleler, ana kayaçtan bir miktar ileriye ötelenir, devrilir ve } \\
\text { dilimleme aşamasına geçilir. }\end{array}$ \\
\hline Kesme yöntemlerinden biri kullanılarak kütle daha küçük ebatlı bloklara (dilimleme) \\
ayrılır. Blokların bazıları çeşitli nedenlerden ötürü (sahadaki süreksizlikler ya da \\
üretim sırasındaki düzensiz parçalanmalar vb.) geometrik şekle sahip olmamaktadır. \\
Bu blokların kenarlarının düzeltilmesi (sayalama) gerekmektedir. Dilimleme ve \\
sayalama işlemleriyle, bloklar taşıabilir ve kesilebilir (katrak makinaları ya da elmas \\
diskli kesicilere uygun) boyutlara getirilmektir.
\end{tabular}

\section{DOĞALTAŞ ATIKLARININ KULLANIM ALANLARI}

Doğaltaş atıkları, çeşitli şekillerde değerlendirilip ekonomik katma değeri olan ürünlere dönüştürülebilmektedir. Bu atıklar; yapı malzemesi üretiminde, yol yapımında, beton üretiminde, dolgu ve cam endüstrisinde ve diğer bazı uygulamalarda kullanılabilmektedir. Ayrıca, sert atıkların aşındırıcı olarak değerlendirilebilmesine yönelik de çeşitli çalışmalar bulunmaktadır. Aşağıda, bu kullanım alanlarına yönelik çeşitli değerlendirmeler yapılmıştır. 

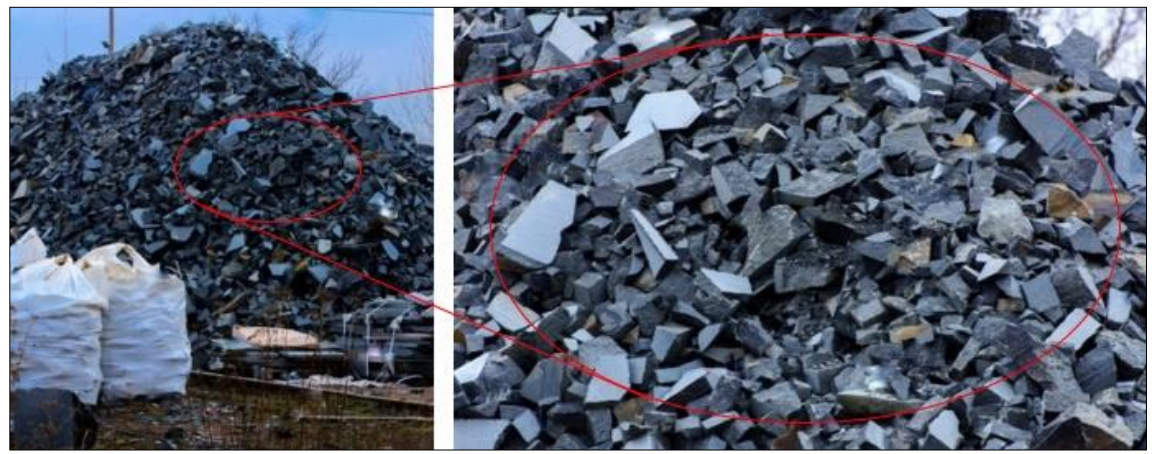

Şekil 1. Ocak atıklarına ait temsili bir görüntü [32]

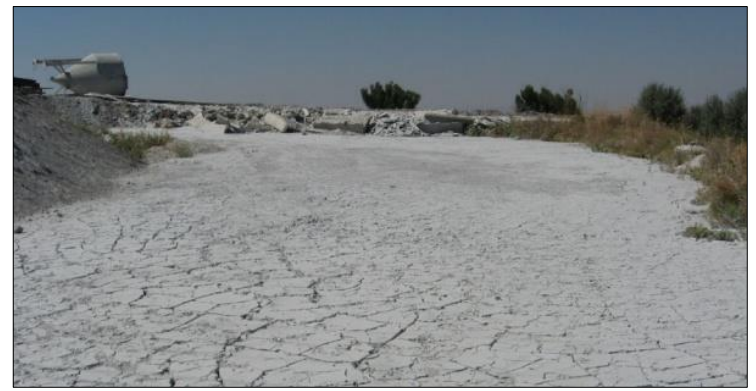

Şekil 2. Fabrika atıklarına ait temsili bir görüntü [33]

\subsection{Yapı Malzemesi Üretiminde Kullanım}

Seramik üretiminde, $\mathrm{CaO}$ kullanılarak ürünün plastikliği ve dayanımı arttırılabilmektedir. Mermer atık tozlarının kalsinasyonu sonucu elde edilen $\mathrm{CaO}$, seramik üretiminde kullanılabilmektedir. $\mathrm{CaO}, \mathrm{CaCO}_{3}$ 'ün firınlarda $1100-1200^{\circ} \mathrm{C}$ 'de pişirilmesiyle ekonomik bir şekilde elde edilebilmektedir. Elde edilen ürünlerde leke oluşumunun meydana gelmemesi için atığın az miktarda demiroksit ve kromoksit içermesi gerekir. Toz içeriğinden belirtilen kirleticilerin uzaklaştırılması için manyetik ayırıcılar kullanılabilir [14,34,35]. Bunun yanında, mermer atıkları porselen karo üretiminde kullanılabilmektedir. Mermer kesim atığının porselen üretiminde uygun oranlarda (ağırlıkça \%3-6) kullanmasıyla sinterleme davranışları iyileşmekte ve hammadde maliyeti (albit hammaddesini yerine kullanılmaları) azalmaktadır [36]. Seramik yapıştırma harcının üretiminde de mermer atık tozlarının kullanılması mümkündür. Kuma belirli oranlarda (yaklaşık \%30) eklenen atık mermer tozu eklenmesiyle, harç standart yapışma kabiliyetine, yüksek basınç ve eğilme dayanımına ve düşük su emme/poroziteye sahip olmaktadır [37]. Bunun yanında, granit atıkları geleneksel seramik hammaddeleri ile fiziksel ve mineralojik olarak benzer özelliklere sahiptir. Bu açıdan granit atıklarının seramik hammaddesi olarak da değerlendirilebilmesi mümkündür [38]. Ek olarak, granit atıkları bileşimlerine bağlı olarak fayans üretiminde kullanılabilmektedir. \%30 granit (muskovit granit) atığı içeren fayanslar yüksek birim hacim ağırlık, eğilme, basma dayanımı ve düşük su emme değerlerine sahiptirler [39].

Mermer atığı mat sır bileşimlerinde renklendirici ve ergitici bir bileşen olarak değerlendirilebilmektedir. Sır bileşiminde mermer atı̆̆1 kullanılmasıyla dekoratif sirlar elde edilebilmektedir. Standart sir bileşimindeki mermer ve kaolenin yerine aynı miktarlarda mermer atığı kullanılarak sır yüzeylerinde farklı renk ve dokular elde edilebilir. Mermer atıkları sırın beyazlık değerini bir miktar yükseltmekte ve parlaklık değerini düşürmektedir. Atık ilavesiyle ergime davranışında önemli bir değişiklik meydana gelmemektedir. $\% 22$ oranında atık ilave edilerek üretilen sırlarda çatlaksız ve pürüzsüz yüzeyler elde edilmektedir [40]. Doğaltaş atıklarının değerlendirilebileceği bir diğer alan tuğla-kiremit üretimidir. Belirli bir oranda 
(yaklaşık \%10) granit atı̆̆ içeren kiremitler su emme, piroplastik deformasyon indeksi ve eğilme dayanımı açısından mükemmel özellikler sunmaktadır [41]. Tuğla bileşimine atıkların (granit ve mermer kesme atıkları) eklenmesi (kil ile \%50 oranına kadar karıştırılması) ile tuğlanın birim hacim ağırlık, basma dayanımı ve eğilme dayanımı artırılabilmektedir [42]. Ayrıca, nihai ürünün teknik özelliklerini etkilemeden \%10'luk mermer tozu atığ tuğla harcına eklenebilmektedir. Bu oranın üzerinde yapılan karışımlarda su emme artmakta ve mekanik özellikler azalmaktadır. Tuğla sertliği ise mermer tozu miktarındaki artışa paralel olarak artmaktadır. Karışım öncesinde kalsiyum oksitin kalsine edilmesiyle daha iyi özelliklere sahip nihai ürün elde edilebilmektedir [43,44].

\subsection{Yol Yapımında Kullanım}

Esnek ve rijit kaplamaya sahip yollarda kullanılan malzemelerin \%95'i agregalardan oluşmaktadır. Bu agregalar, civardaki agrega ocaklarından veya doğal agrega kaynaklarından temin edilmektedir. Bu faaliyetlerden ötürü yeryüzünün genel yapısı bozulmakta ve çevresel açıdan istemeyen görüntüler [28,45]. Atık doğal taşlar (parça ve toz), asfalt kaplamalarda agrega (sürtünme tabakası ve binder tabakalarında), ince malzeme veya bağlayıcı katkı olarak kullanılabilir.

Asfalt yol kaplamalarında kullanılabilmeleri için doğaltaş atıklarının sürtünmeye karşı dirençlerinin tespit edilmesi gerekir. Aşırı sürtünmeye maruz kalan bu bölgelerde kullanılacak agregaların cilalanma dirençlerinin 45'ten yüksek olması gerekmektedir [46]. Bilindiği gibi, agrega yüzeyindeki pürüzlü tabakalar kaplama üzerinde biriken tozlar tarafından aşındırılırlar. Agregalardaki minerallerin sertliklerinin düşük olması bu süreci hızlandırmaktadır. Bunun yanında, agreganın sert ve yumuşak minerallerden oluşması yüzey pürüzlülüğü açısından avantaj sağlamaktadır. Aşınma sırasında, düşük sertlikteki mineraller silinip çukurlaşmakta, sert mineraller ise çıkıntı olarak kalmaktadır. $\mathrm{Bu}$ şekilde oluşan pürüzlülük kayma direncinin iyileştirilmesine imkân sağlamaktadır. İdeal bir agrega yarı yarıya sert ve düşük sertlikteki mineraller içermelidir. Cilalanma mukavemeti açısından agrega olarak değerlendirilebilecek en uygun atıklar bazalt, granit, diyorit gibi magmatik ve metamorfik kökenli doğal taşların sert ocak atıklarıdır [21,28,47]. Aşırı sürtünmeye maruz kalan sürtünme tabakasında kullanılamayacak doğal taş atıkları ise (cilalanma dirençleri 45'ten düşük) binder tabakasında (sürtünme tabakasının alt kısmında bulunan ve sürtünmeye maruz kalmayan bölge) kullanılabilir [46]. Bu katmanın işlevi, yüzeyden gelen yükleri yapıya zarar vermeden alt tabakaya iletmektir.

Kaplama malzemesinde kullanılan bağlayıcı, kaplama bileşimdeki kaba agregalar ve yüksek karışım sıcaklığı nedeniyle tabakanın alt kısmına doğru akmaktadır. Bu ise bağlayıcının karışımın içerisinde eşit olarak dağıtılamamasına yol açmaktadır. Ayrıca, sıcaklıkların yüksek olduğu bölgelerde yol yüzeyinde kullanılan bağlayıcılarda erime meydana gelmektedir. Bunun sonucunda, agrega ile bağlayıcı arasındaki yapışma kuvveti zayıflamakta ve agregalar dış etkenlerle bileşimden ayrılmaktadır. Bu agregalar, yolun belirli bölgelerinde birikerek trafik açısından sorun oluşturmaktadır. Ayrıca, yolun yüzey sürtünme katsayısını azaltmakta ve aşınmayı hızlandırmaktadır. Atık mermer tozunun filler malzemesi olarak kullanılmasıyla bağlayıcı malzemenin viskozitesi arttırılabilmekte ve bu problemin önüne geçilmektedir [46].

Yol, temel ve temel altı tabaklarında kullanılan malzemelerin belirli bir rutubet oranında sıkışabilmesi gerekmektedir. Optimum sıkışmanın sağlanabilmesi için killi malzemelere ihtiyaç duyulmaktadır. Bu amaçla, çok ince boyutlu ve kireç içeren doğaltaş atıkları kullanılabilmektedir [48,49].

\subsection{Beton Üretiminde Kullanım}

Devamlı gelişim gösteren inşaat sektöründe agregaya olan talep sürekli artmaktadır. Beton üretiminde iri (4-8 $\mathrm{mm}$ ve 8-31,5 mm çapında kırma taş/çakıl) ve ince (0-4 mm çapında kum/kırma taş tozu) agregalar kullanılmaktadır [50]. Doğaltaş atıkları iri ve ince beton agregası olarak kullanılabilmektedir [51,52]. Parça doğaltaş atıkları endüstriyel olarak özellikle hazır beton tesislerinde beton üretiminde agrega olarak kullanılabilmektedir [52]. Beton bileşiminde doğal agregalarla gerçekleştirilen \%75'lik atık değişimlerde 
yüksek beton direnci elde edilebilmektedir [53]. Doğal taşların agrega özellikleri büyük ölçüde petrografik özellikler tarafindan kontrol edilmektedir [54-56] İnce kesit incelemelerinde bazı doğaltaş türlerine (traverten) ait atıkların çimento malzemesi ile oldukça iyi kenetlendiği gözlenmiştir [56,57]. Doğaltaş toz atıklarını (özellikler mermer ve kireçtaşı) içeren betonlar iyi işletilebilirliğe sahiptirler. Bu betonların aşınma dirençleri geleneksel betonla benzerlik taşımaktadır. Bunun yanında, betonun aşınma ve sodyum sülfat direnci, doğaltaş toz atığının karışım içerisindeki oranının artmasıyla (\%5-15 aralığı için) artmaktadır [58]. Granit kesme atığı ile ince agreganın optimum değişim oranını yaklaşık olarak \%30'dur [59-61]. Betonun performansı bu değişim seviyelerinde önemli bir şekilde artmaktadır. Granit kesme atığının ince agregayla \%25'lik bir optimum değişiminde betonun asit saldırısı, karbonatlama, klorür etkisi ve artan sıcaklığın kötü tesir koşulları altında üstün performans sergilemektedir [62]. Betonun basma ve eğilme dayanımı kumun kısmi bir değişkeni olarak granit tozunun eklenmesiyle artmaktadır. Granit tozunun kum ile \%10 oranındaki değişimlerinde elde edilen betonlar basma ve eğilme dayanımı açısından iyi sonuçlar vermektedir [63]. Karışık atık tozları (granit ve mermer tozu) içeren kendiliğinden yerleşen betonlar da üstün performans sergilemektedir [64].

\subsection{Aşındırıcı Olarak Kullanım}

Aşındırıcılı sujeti kesme (ASJ) yöntemi, doğaltaş sektöründe kullanılan alternatif bir kesme teknolojisi olarak ön plana çıkmaktadır. Bu yöntemde, bir memeden (nozül) çıkan yüksek basınçtaki jet (su ve aşındırıcı bileşimli) yüksek hızla doğaltaş yüzeyine çarpmakta ve kesme/aşındırma işlemi gerçekleşmektedir [65]. Bu yöntemde diğer geleneksel kesme yöntemlerinde karşılaşılan problemler (kesim yüzeyinde 1s1 kaynaklı problemler, kesme aracının kırılması, yüksek kesme kuvvetleri vb.) görülmemektedir. ASJ yönteminin kesme performansı kullanılan aşındırıcının çeşitli özelliklerinden etkilenmektedir [66]. Herhangi bir malzemenin kesilmesinde uygun aşındırıcının tipinin belirlenebilmesi için aşındırıcıların su ile reaksiyon göstermemesi ve sertlik, dayanım, yoğunluk ve şekilsel özellikler açısından gereksinimleri karşılaması gerekmektedir [67,68]. Doğaltaş atıklarının belirtilen durumlar açısından irdelenmesiyle aşındırıcı olarak kullanım potansiyelleri belirlenebilir. Bu kapsamda, özellikle sert granit atıklarının aşındırıcı olarak kullanılabilirliği akla gelebilir.

Granitler, başlıca feldspat, kuvars ve plajiyoklaz gibi minerallerden oluşmaktadır. Granit atıklarının bileşiminde su ile reaksiyona girecek herhangi bir mineralin bulunmadığı söylenebilir. Fowler ve ark. [69] aşındırıcının setliğinin kesme performansı açısından önemli etkiye sahip olduğunu belirtmiştir. Granitin bileşiminde bulunan başlıca kayaç yapıcı minerallerin her birinin sertliği (Mohs Sertlik Skalası) 6'nın üzerindedir. Bu, garnetin (ASJ kesme uygulamalarında yaygın kullanıma sahip aşındırıcı) sertliğiyle (yaklaşık 7) kıyasladığında yakın bir değer olarak dikkat çekmektedir. Aşındırıcının kesme performansı aşındırıcının dayanımından da etkilenmektedir. Bilindiği gibi aşındırıcı tanecikler kesme, odaklama ve ivmelenme proseslerinde parçalanmaktadırlar. Aşındırıcı tanelerin parçalanması karışım odası/odaklama tüpü (aşındırıcı-aşındırıcı, aşındırıcı-jet ve aşındırıcı-duvar çarpışması) ve malzeme kesme yüzeylerinde (aşındırıcı-aşındırıcı ve aşındırıcı-malzeme çarpışması) gerçekleşmektedir [70,71]. Çok kırılgan olan aşındırıcılar odaklama tüpünde parçalanmakta ve malzemeyi etkili bir biçimde kesememektedir. Diğer taraftan çok sağlam olan aşındırıcılar ise karışım süreçlerinde yuvarlanmakta ve aşındırıcı körelmesinden ötürü etkisiz kesme koşullarının oluşmasına sebep olmaktadır. Bu sebepten ideal aşındırıcının belirli bir parçalanma oranına sahip olması gerekir. Granitin mineralojik bileşiminin dayanım açısından ihtiyaç duyulan kriterleri karşılayacağı düşünülmektedir. Aşındırıcının şekli, kesme performansını etkileyen bir başka kriter olarak ön plana çıkmaktadır. Bilindiği gibi aşındırıcılar farklı şekil ve boyutlara sahip olabilmektedir. Yuvarlak ve keskin köşeli aşındırıcılar ASJ kesme uygulamalarında yaygın olarak kullanılmaktadır. Bir su akıntısı içerisinde kütlenin taşınması için ideal şekil olarak genellikle küre akla gelmektedir. Ancak aşındırıcıların ivmelenmesi ve parçalanması etkili bir kesim için dengede tutulmalıdır. Granit atıklarının tane şekillerinin garnet ile benzer özelliklere sahip olduğu Şekil 3'te görülmektedir. Farklı performans çıktıları temelinde (kesme genişliği, kesme derinliği, kerf açısı ve yüzey pürüzlülüğü) granit atığı doğaltaş kesme işlemlerinde bir aşındırıcı olarak gereksinimleri karşılayabilir [72]. Granit atıkları sedimanter kökenli (yüksek kalsiyum oksit içeriğine ve düşük sertliğe sahip) doğal taşların aşındırma 
proseslerinde yapay aşındırıcı olarak da kullanılabilmektedir. Granit atıklarıyla gerçekleştirilen aşındırmalarla parlaklıkları arttırılan doğaltaş yüzeylerinin pürüzlülükleri bir miktar azalmaktadır. Ayrıca, granit atığının boyutu küçüldükçe doğaltaş yüzeylerinin pürüzlülüğü artmakta, parlaklığı ise azalmaktadır [73].

\subsection{Dolgu ve Cam Endüstrisinde Kullanım}

Dünya ölçeğinde kâğıt üretiminde geri dönüşüm oranı (\%40) oldukça yüksektir. Kâğıt üretiminde paya sahip diğer kaynaklar ise sirasıyla kimyasal selüloz, mekanik odun selülozu, pigment/dolgu maddeleri ve kimyasal katkı maddeleridir [74]. Lifsel hammadde kullanımını azaltmak için kâğıt/karton üretiminde çeşitli dolgu maddeleri kullanılmaktadır. Dolgu maddeleri genelde kağıdın beyazlığını, baskı kalitesini ve yüzey özelliklerini iyileştirmektedir [75] Kalsiyum karbonat kâğıt-karton üretiminde dolgu ve kaplama pigmenti olarak kullanılmaktadır. $\mathrm{CaCO}_{3}$ kökenli kayaçlar yüksek beyazlık ve kırılma indeksinin yanında ince tane boyutuna sahip olmalarından ötürü kalsiyum karbonat elde edilmesinde yaygın olarak tercih edilmektedir. Kâğıdın dayanıklılığını da arttıran bu kayaçlar, tebeşir, kireçtaşı ve mermerdir [76].
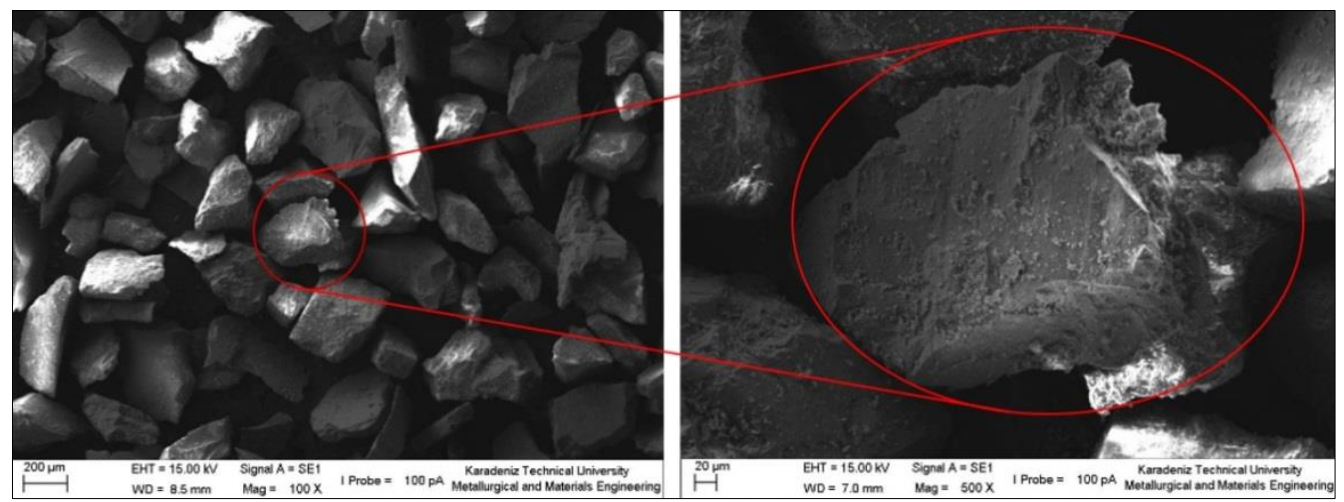

Şekil 3. Bir granit atığına ait taramalı elektron mikroskobu görüntüleri (temsili) [72]

Belirtilen doğaltaşların toz atıklarının bu kapsamda değerlendirilebilmesi mümkündür. Dolgu ve kaplama (ilk veya mat kaplamalarda) amaçlı kullanımlarda $\mathrm{CaCO}_{3}$ oranı sırasıyla \%40-80 ve \%60 civarındadır [34]. Seramik; uygulama sonrasında uzun ömürlü ve dayanıklı olmalarını sağlamak, parça aralarından kaplanan malzemenin tabanına doğru oluşabilecek su sızıntısını önlemek, kaplanan malzemenin sabitlenmesini pekiştirmek ve yalıtım sağlamak amacıyla doğal ve dökme taşların uygulamalarında derz dolgusu olarak kullanılmaktadır. Derz dolgu malzemesi, su iticilik, çatlamama, suya karşı direnç gösterme ve renk değiştirmeme özelliklerine sahiptir. Atık mermer tozları, derz dolgu malzemesi üretiminde kullanılabilmektedir. Ancak, bu amaçla öncelikle kurutulması, içeriğindeki istenmeyen bileşenlerin temizlenmesi ve öğütülmesi gerekmektedir. Bu işlemlerin maliyeti ve ihtiyaç duyulan zaman mermer toz atıklarının bu sektörde değerlendirilmesi açısından dezavantaj oluşturmaktadır [34].

Cam endüstrisinde ise ham madde olarak $\mathrm{CaO}$ kullanılmaktadır. $\mathrm{Bu}$ hammadde mermer toz atıklarının kalsinasyonu ile elde edilebilir. Demir oksit içeriği \%1'in altında olan mermer tozları renksiz, üzerinde olanlar ise renkli cam üretiminde kullanılabilir. Bu kapsamda atıkların değerlendirilebilmesi için atıkların aşırı miktarlarda organik madde içermemesi gerekmektedir [14,34]. Bunun yanında, camın dayanımını arttırmak için (\% 10 oranına kadar) kalsiyum karbonat ve dolomit kullanılmaktadır. Kimyasal analizler atık mermer tozunun başlica kalsiyum karbonat ve dolomit minerallerinden oluştuğunu göstermektedir. Dolayısıyla, mermer toz atıkları cam üretiminde kullanılabilir. 


\subsection{Diğer Alanlarda Kullanım}

Yukarıda bahsedilen kullanım alanlarına ek olarak doğaltaş atıkları; taşkın önleme barikatı yapımında, toprağın nötralizasyonunun sağlanmasında, endüstriyel hammadde ihtiyacının karşılanmasında, çimentoboya-plastik üretiminde, filtreleme işlemlerinde ve yem sanayinde kullanılabilmektedir. Tablo 8'de bu kullanım alanlarına yönelik bir değerlendirme sunulmuştur.

Tablo 8. Doğaltaş atıklarının diğer kullanım alanları

\begin{tabular}{|c|c|}
\hline Kullanım alanı & Açıklama \\
\hline $\begin{array}{l}\text { Taşkın önleme } \\
\text { barikatı }\end{array}$ & $\begin{array}{l}\text { İlave bir kaya ocağı işletmesine ihtiyaç bırakmayacak şekilde doğaltaş atıkları taşkın } \\
\text { önleme barikatı yapımında kullanılabilir [27]. }\end{array}$ \\
\hline $\begin{array}{l}\text { Toprağın } \\
\text { nötralizasyonu }\end{array}$ & $\begin{array}{l}\text { Mermer atıkları asidik toprağın nötralizasyonunun sağlanmasında kullanılabilir. } \\
\text { Mermer kesme atıklarının fındık tarlalarında kullanımıyla ürün miktarı artmaktadır } \\
\text { [77]. }\end{array}$ \\
\hline Hammadde & $\begin{array}{l}\text { Mermer atıkları hafif iyileştirmeler ile farklı endüstriyel uygulamalarda bir hammadde } \\
\text { olarak kullanılabilir [78]). }\end{array}$ \\
\hline Çimento & $\begin{array}{l}\text { Çimento üretiminde katkı malzemesi olarak aranılan özellikleri sağlayan mermer atık } \\
\text { tozları çimento üretiminde katkı malzemesi olarak kullanılabilir [79-81]. }\end{array}$ \\
\hline Boya endüstrisi & $\begin{array}{l}\text { Renk ve görünümün önemsenmediği boyaların üretiminde dolgu maddesi olarak ince } \\
\text { boyutlu mermer atıkları kullanılabilir }[14,34] \text {. }\end{array}$ \\
\hline Plastik üretimi & $\begin{array}{l}\text { Tane boyutu } 40 \text { mikron atındaki kalsiyum karbonat, plastik üretiminde dolgu } \\
\text { malzemesi olarak kullanılmaktadır. Mermer toz atıklarının bu kapsamda } \\
\text { değerlendirilmesi mümkündür [82] }\end{array}$ \\
\hline Filtre malzemesi & $\begin{array}{l}\text { Katı yakıtların tüketimi nedeniyle oluşan hava kirliliğini (yüksek oranda } \mathrm{SO}_{2} \\
\text { emisyonu) önlemek amacıyla mermer toz atıkları }\left(\mathrm{SO}_{2} \text { tutma verimleri yaklaşık \%80) }\right. \\
\text { kullanılabilir. }\end{array}$ \\
\hline Şeker endüstrisi & $\begin{array}{l}\text { Kalsiyum karbonatın ısıtılmasıyla elde edilen } \mathrm{CaO} \text {, şeker sanayinde pancar şerbeti veya } \\
\text { şeker kamışının arıtılmasında kullanılmaktadır. Kalsiyum karbonat içeriği \%95 ve } \\
\text { üzeri olan mermer atık tozları şeker endüstrisinde kullanılabilir [82]. }\end{array}$ \\
\hline Yem endüstrisi & $\begin{array}{l}\text { Kanatlı hayvan ve büyükbaş hayvan yemlerinde kalsiyum (yumurta kabuğu } \\
\text { oluşumunda ve hayvanların kemik gelişimde önemli) kaynağı olarak mermer tozu } \\
\text { kullanılmaktadır [83]. }\end{array}$ \\
\hline
\end{tabular}

\section{SONUÇLAR VE ÖNERİLER}

Çalışmanın sonuçlarını ve önerilerini aşağıdaki gibi özetlemek mümkündür.

i. Doğaltaş atıkları, yükleme ve taşıma aşamalarından sonra pasa döküm sahalarına (uzak bölgelerdeki boş araziler, tarım arazileri veya işletme sahası) boşaltılmaktadır. Atıkların farklı alanlarda depolanması üretim maliyetlerini (nakliyeden dolayı) arttırmaktadır. İşletme sahası içerisinde gerçekleştirilen depolamalarda ise saha kullanma verimi azalmaktadır. Bunun yanında doğaltaş atıkları, topografya değişikliliği, yüzey ve yeraltı sularında bozulma, hava/görüntü kirliliği gibi çevresel etkiler yaratmaktadır. Doğaltaş atıkların geri kazanımı ve yeniden kullanımıyla bahsedilen problemlerin önüne geçilebilecektir.

ii. Doğaltaş atıklarının, yapı malzemesi ve beton üretimi, yol yapımı, dolgu ve cam endüstrisi başta olmak üzere bazı diğer uygulamalarda kullanılabilmesi mümkündür. Ayrıca, granit gibi sert doğaltaş atıkları, ASJ ile kayaç kesme uygulamaları başta olmak üzere farklı uygulamalarda (doğal taşların aşındırma prosesleri gibi) aşındırıcı malzeme olarak değerlendirilebilmektedir.

iii. Dayanıklı olmaları ve görsel açıdan güzel bir görünüm sunmaları sebebiyle doğal taşlar, tarih boyunca birçok alanda kullanılmıştır. Günümüzde ise doğal taşlar yaygın olarak inşaat sektöründe iç ve dış mekânların kaplanmasında kullanılmaktadır. Ancak, ocaklarda ve fabrikalarda yürütülen kesme/işleme faaliyetlerine bağlı olarak üretimin \%40-70'i atık olarak kaybedilmektedir. Doğaltaşların üretimi ve işlenmesi sırasında ortaya çıkan atıkların çalışmada bahsedilen alanlarda 
kullanımıyla endüstriyel kazanç sağlanacak ve atığın yaratacağı çevresel problemler minimize edilebilecektir. Ek olarak, doğaltaş atıklarının değerlendirilmesi konusunda bulunabilecek alternatifler, doğaltaş işletmecilerine ve ülke ekonomisine önemli katkı sağlayacaktır.

\section{REFERANSLAR}

[1] Aydın G., Karakurt İ., Aydıner K (2012). "Performance of abrasive waterjet in granite cutting: Influence of the textural properties". Journal of Materials in Civil Engineering 24 (7), 944-949.

[2] Aydın G., Karakurt İ., Aydıner K (2013a). "Prediction of cut depth of the granitic rocks machined by abrasive waterjet (AWJ)". Rock Mechanics and Rock Engineering 46 (5), 1223-1235.

[3] Erkanol D., Aydındağ A (2013). “Türkiye geneli doğal taş potansiyel alanlarının belirlenmesi projesi”. Erişim Tarihi 28 Aralı 2019. http://www.mta.gov.tr/v3.0/sayfalar/hizmetler/kutuphane/ekonomibultenleri/2013_16/147.pdf

[4] Aydın G., Karakurt İ., Aydıner K (2013b). "Wear performance of saw blades in processing of granitic rocks and development of models for wear estimation". Rock Mechanics and Rock Engineering 46 (6), 1559-157.

[5] Karakurt I., Aydın G., Aydıner K (2014). "An investigation on the kerf width in abrasive waterjet cutting of granitic rocks". Arabian Journal of Geosciences 7(7), 2923-2932.

[6] Karakurt I, Aydın G, Aydıner K (2013a). "Predictive modelling of noise level generated during sawing of rocks by circular diamond sawblades”. Sadhana-Academy Proceedings in Engineering Science 38(3), 491-511.

[7] Karakurt İ, Aydın G, Aydıner K (2013b). "Experimental and statistical analysis of cutting force acting on diamond sawblade in sawing of granitic rocks". Proceedings of the Institution of Mechanical Engineers, Part B: Journal of Engineering Manufacture 227, 286-300.

[8] TB (2018). “Doğal taşlar sektör raporu”. Ticaret Bakanlığı, İhracat Genel Müdürlüğü: Maden, Metal ve Orman Ürünleri Dairesi. 9 sayfa, https://ticaret.gov.tr/data/5b87000813b8761450e18d7b/Dogal_Taslar_2020.pdf, Erişim tarihi 01.07.2020.

[9] Yalçın S., Uyanık T (2001). “Dünya mermer ticaretinde Türkiye'nin yeri”. Türkiye III. Mermer Sempozyumu, 3-5 May1s 2001, Afyon, 397-416.

[10] Çetin T., (2003). "Türkiye mermer potansiyeli, üretimi ve ihracatı”. GÜ Gazi Eğitim Fakültesi Dergisi 23(3), 243-256.

[11] Korkmaz E (2016). “Türkiye'de doğal taş ve nermer madenciliği ile dış ticaret ilişkisi”. Paradigma 1(1), 35-46.

[12] Azizoğlu M.S (2005). "Çukurova bölgesindeki mermer ocaklarının pazar durumu ve ekonomik açıdan değerlendirilmesi”. Yüksek Lisans Tezi, Çukurova Üniversitesi, Fen Bilimleri Enstitüsü, Adana, 114 sayfa.

[13] Büyüksağış İ.S., Gürcan S (2005). “ASTM ve TSE doğal taş standartlarının karşılaştırılması”. Madencilik 44 (1), 33-41.

[14] Şentürk A., Gündüz L., Tosun Y.İ., Sarış̧k A (1996). “Mermer Teknolojisi”. Tuğra Offset, Isparta, 242 s.

[15] Çelik M.Y (2003). "Dekoratif doğal yapı taşlarının kullanım alanları ve çeşitleri”. Madencilik, 42(1), 3-15.

[16] Taşlıgil N., Şahin G (2016). "Yapı malzemesi olarak kullanılan Türkiye doğal taşlarının iktisadi coğrafya odağında analizi”. Maramara Coğrafya Dergisi 33, 607-640.

[17] Çetin T (2003). "Doğal ortam-ekonomik faaliyet ilişkisine bir örnek: Kozak yöresi (Bergama)". Gazi Üniversitesi Gazi Eğitim Fakültesi Dergisi, 23(1), 23-46. 
[18] Kulaksız S (2012). "Doğal Taş (Mermer) maden işletmeciliği ve işleme teknolojileri. TMMOB Maden Mündisleri Odası Yayını 636 sayfa.

[19] Ersoy M (2010). "Mermer ocaklarında delme çatlatma yönteminde üretim planlaması ve hesap çizelgesi programında uygulanması”. TÜBAV Bilim Dergisi 3(1), 23-34.

[20] Aydin G., Karakurt İ., Aydiner K (2013d). "Development of predictive models for specific energy of circular diamond sawblades in sawing of granitic rocks". Rock Mechanics and Rock Engineering 46 (4), 767-783.

[21] Soltan A.M.M., Kahl W., El-Raoof F.A., Abdel-Hamid B (2016). "Lightweight aggregates from mixtures of granite wastes with clay”. Journal of Cleaner Production 117, 139-149.

[22] Ural N., Yakşe G (2015). “Atık mermer parçalarının yol temel malzemesi olarak değerlendirilmesi”. Bilecik Şeyh Edebali Üniversitesi Fen Bilimleri Dergisi 2(2), 53-62.

[23] Yıldız A.H (2008). "Mermer toz atıklarının yol inşaatında değerlendirilmesi.” Doktora Tezi, Fen Bilimleri Enstitüsü, Süleyman Demirel Üniversitesi, Isparta, 194 s.

[24] Aydın G, Karakurt I, Hamzaçebi C (2015). "Performance prediction of diamond sawblades using artificial neural network and regression analysis”. The Arabian Journal for Science and Engineering 40, 2003-2012.

[25] Aydin G (2014). "Recycling of abrasives in abrasive water jet cutting with different types of granite". Arabian Journal of Geosciences 7 (10), 4425-4435.

[26] Aydin G (2015). "Performance of recycling abrasives in rock cutting by abrasive waterjet". Journal of Central South University 22 (3), 1055-1061.

[27] Çavuş U.Ş (2015). "Mermer parça atıklarının taşkın koruma ve akarsu yatakları ıslah yapılarında kullanımı”. Afyon Kocatepe Üniversitesi Fen ve Mühendislik Dergisi 15, 19-28.

[28] Akbulut H., Gürer, C (2006). “Atık mermerlerin asfalt kaplamalarda agrega olarak değerlendirilmesi”. İMO Teknik Dergi 261, 3943-3960.

[29] Görgün B., Ural N (2015). “Mermer atı̆̆ının geoteknik mühendisliğinde kullanılması”. II. International Sustainable Buildings Symposium, 28-30 May 2015 Ankara, Turkey, 219-132.

[30] Aydin G., Karakurt I., Aydiner K (2013c). "Investigation of the surface roughness of rocks sawn by diamond sawblades". International Journal of Rock Mechanics and Mining Sciences 61, 171-182.

[31] Celep O., Aydın G., Karakurt İ (2013). "Diamond recovery from waste sawblades: A preliminary investigation”. Proceedings of the Institution of Mechanical Engineers, Part B: Journal of Engineering Manufacture 227, 417421.

[32] URL-1 (2018). Erişim tarihi 18 Aralık 2018 https://www.alamy.com

[33] Sivrikaya O., Kiyıldı K.R., Karaca Z (2014). Recycling waste from natural stone processing plants to stabilise clayey soil". Environmental Earth Sciences 71, 4397-4407.

[34] Ceylan H (2000). “Mermer fabrikalarındaki mermer toz atıklarının ekonomik olarak değerlendirilmesi”. Yüksek Lisans Tezi, Fen Bilimleri Enstitüsü, Süleyman Demirel Üniversitesi, Isparta, 53 sayfa.

[35] Yıldız Ö., Eskikaya Ş (1995). “Afyon mermeri toz atıklarının değerlendirilmesi”. Türkiye I. Mermer Sempozyumu, 6-7 Nisan 1995, Ankara, 45-52. 
[36] Kayacı K., Köstebekçi N., Küçüker A.S., Uzun M., Kara A (2018). "Mermer kesim ve frit atıklarının porselen karo bünyelerinde beraber kullanımı". Afyon Kocatepe Üniversitesi Fen Bilimleri Dergisi (Özel Say1), 1-8.

[37] Kürklü G., Görhan G., Boğa A.R (2018). “Atık mermer tozlarının seramik yapıştırma harcı olarak değerlendirilmesi”. Afyon Kocatepe Üniversitesi Fen ve Mühendislik Bilimleri Dergisi 18, 295- 305.

[38] Menezes R.R., Ferreira H.S., Neves G.A., Ferreira H.C (2008). "se of granite sawing waste in the production of ceramic bricks and tiles". Journal of the European Ceramic Society 25(7), 1149-1158.

[39] Hojamberdiev M., Eminov A., Xu Y (2011). "Utilization of muscovite granite waste in the manufacture of ceramic tiles". Ceramics International 37, 871-876.

[40] Yeşilay S (2018). "Mermer atığı ilavesi ile mat sır bileşimlerinin üretimi”. Eskiş̧ehir Osmangazi Üniversitesi Mühendislik ve Mimarlık Fakültesi Dergisi 26(3), 123-131.

[41] Torres P., Fernandes H.R., Olhero S., Ferreira J.M.F., Torres P., Fernandes H.R., Olhero S., Ferreira J.M.F (2009). "Incorporation of wastes from granite rock cutting and polishing industries to produce roof tiles". Journal of the European Ceramic Society 29, 23-30.

[42] Dhanapandian S., Gnanavel B., Ramkumar T (2009). "Utilization of granite and marble sawing powder wastes as brick materials". Carpathian Journal of Earth and Environmental Sciences" 4(2), 147-160.

[43] Bilgin N., Yeprem H.A., Arslan S., Bilgin A., Gunay E., Marsoglu M (2012). "Use of waste marble powder in brick industry". Construction and Building Materials 29, 449-457.

[44] Cobo-Ceacero C.J.C., Cotes-Palomino M.T., Martínez-García C., Moreno-Maroto J.M., Uceda-Rodríguez M (2018). "Use of marble sludge waste in the manufacture of eco-friendly materials: applying the principles of the Circular Economy. http://uest.ntua.gr/naxos2018/proceedings/pdf/119_NAXOS2018_CoboCeacero_etal.pdf

[45] Gürer C (2004). “Atık mermer parçalarının bitümlü yol kaplamalarında kullanılması”. Yüksek Lisans Tezi, Fen Bilimleri Enstitüsü, Afyon Kocatepe Üniversitesi, 91 sayfa.

[46] Akbulut H., İçağa Y., Gürer C (2003). "Atık agregaların asfalt yol kaplamalarında tekrar kullanım imkanları ve CEN standartları”. III. Ulusal Kırmataş Sempozyumu, 3-4 Aralık 2003, 271-276.

[47] Karakus A (2011). "Investigating on possible use of Diyarbakir basalt waste in Stone Mastic Asphalt". Construction and Building Materials 25, 3502-3507.

[48] Akbulut H., Gürer C (2003). "Mermer atıklarının çevresel etkileri ve yol katmanlarında kullanarak faydalanma ve atık azaltma imkanları". Türkiye IV. Mermer Sempozyumu Bildiriler Kitabı, 18-19 Aralık 2003; s.371-378.

[49] Ergezer F (2018). "Sıcak Çermik Bölgesi (Sivas) traverten atıklarının yol temel ve alt temel tabakalarında kullanılabilirliğinin araştırılması”. Süleyman Demirel Üniversitesi Fen Bilimleri Enstitüsü Dergisi 22(Özel Say1), 181-188.

[50] Ünal O., Kibici Y (2001). “Mermer tozu atıklarının beton üretiminde kullanılmasının araştırılması”. Türkiye III. Mermer Sempozyumu, 3-5 Mayıs 2001, Afyon, 317-325.

[51] Arsoy Z., Ersoy B., Sert M., Çiftçi H., Çelik M.Y., Evcin A., Yentürk F (2018). "Afyonkarahisar Organize Sanayii Bölgesi mermer atıklarının beton agregası olarak dayanım özelliklerinin belirlenmesi". I. International Engineering and Technology Symposium, 1020-1026.

[52] Ceylan H., Mança S (2013). "Mermer parça atıklarının beton agregası olarak değerlendirilmesi”. Süleyman Demirel Üniversitesi Teknik Bilimler Dergisi 3(2), 21-25. 
[53] Hebhoub H., Aoun H., Belachia M., Houari H., Ghorbel E (2011). "Use of waste marble aggregates in concrete". Construction and Building Materials 25, 1167-1171.

[54] Arslantaş B (2009). "Karaburun kireçtaşı taşocakları atıklarının agrega olarak kullanılmasının araştırılması". Dokuz Eylül Üniversitesi, Fen Bilimleri Enstitüsü, Yüksek Lisans Tezi, 2009. 92 sayfa.

[55] Dursun G (2004). "İstanbul Anadolu yakasındaki kireçtaşlarının agrega kalitesi yönünden değerlendirilmesi”. İstanbul Üniversitesi, Fen Bilimleri Enstitüsü, Yüksek Lisans Tezi, 100 sayfa.

[56] Zarif İ.H., Tuğrul A., Dursun G (2003). "İstanbul'daki kireçtaşlarının agrega kalitesi yönünden değerlendirilmesi”. İstanbul Üniversitesi Mühendislik Fakültesi Yerbilimleri Dergisi 16, 61-70.

[57] Çelik S.B., Çobanoğlu G., Çam O., Etiz H., Kurşun M (2015). "Traverten ocak artıklarının alternatif beton agregası olarak kullanılabilirliğinin araştırılması”. MÜHJEO’2015: Ulusal Mühendislik Jeolojisi Sempozyumu, 3-5 Eylül 2015, Trabzon, 335-342.

[58] Binici H., Kaplan H., Yilmaz S (2007). "Influence of marble and limestone dusts as additives on some mechanical properties of concrete". Scientific Research and Essay 2 (9), 372-379.

[59] Singh S., Khan S., Khandelwal R., Chugh A., Nagar R (2016a). "Performance of sustainable concrete containing granite cutting waste". Journal of Cleaner Production 119, 86-98.

[60] Vijayalakshmi M., Sekar A.S.S., Sivabharathy M., Ganesh Prabhu G (2012). "Utilization of granite powder waste in concrete production". Defect and Diffusion Forum 330, 49-61.

[61] Ünal O., Demir İ., Ergün A (2018). "Mermer tozu katkılı betonların donma-çözülme özelliklerinin araştırılması”. Erişim tarihi 18 Aralık 2019. http://www.imo.org.tr/resimler/ekutuphane/pdf/10619.pdf

[62] Singh S., Nagar R., Agrawal V (2016b). "Performance of granite cutting waste concrete under adverse exposure conditions". Journal of Cleaner Production 127, 172-182.

[63] Ghannam S., Najm H., Vasconez R (2016). "Experimental study of concrete made with granite and iron powders as partial replacement of sand". Sustainable Materials and Technologies 9, 1-9.

[64] Sadek D.M., El-Attar M.M., Ali H.A (2016). "Reusing of marble and granite powders in self-compacting concrete for sustainable development". Journal of Cleaner Production 121, 19-32.

[65] Lebar A., Junkar M (2004). "Simulation of abrasive water jet cutting process: Part 1, Unit event approach". Modelling and Simulation in Materials Science and Engineering 12, 1159- 1170.

[66] Rapple R.R (2014). "Selecting the Right Waterjet Abrasive”. The Fabricator. Erişim tarihi 07 Ekim 2016 http:// www.thefabricator.com/article/waterjetcutting/selecting-the-right-waterjetabrasive

[67] Karakurt İ., Aydın G., Aydıner K (2011). "Analysis of the kerf angle of the granite machined by abrasive waterjet (AWJ)”. Indian Journal of Engineering \& Materials Sciences 18(6), 435-442.

[68] Karakurt İ., Aydın G., Aydıner K (2012). "A study on the prediction of kerf angle in abrasive waterjet machining of rocks". Proceedings of the Institution of Mechanical Engineers, Part B: Journal of Engineering Manufacture 226, 1489-1499.

[69] Fowler G., Pashby I.R., Shipway P.H (2009). "The effect of particle hardness and shape when abrasive water jet milling titanium alloy Ti6A14V". Wear 266, 613-620.

[70] Labus T.J., Neusen K.F., Alberts D.G., Gores T.J (1991). "Factors influencing the particle size distribution in an abrasive waterjet". Transactions of the American Society of Mechanical Engineers, Journal of Engineering for Industry 113, 402-411. 
[71] Babu M.K., Chetty O.V.K (2002). "Studies on recharging of abrasives in abrasive water jet machining". International Journal of Advenced Manufacturing Technology 19, 697-703.

[72] Aydın G., Kaya S., Karakurt I (2017). "Utilization of solid-cutting waste of granite as an alternative abrasive in abrasive waterjet cutting of marble". Journal of Cleaner Production 159, 241-247.

[73] Sarici D.E., Ozdemir E (2018). "Utilization of granite waste as alternative abrasive material in marble grinding processes". Journal of Cleaner Production 201, 516-525.

[74] Duman E (2015). “Taş Kağıt türünün basılabilirlik parametrelerinin belirlenmesi”. Marmara Üniversitesi Fen Bilimleri Enstitüsü, Yüksek Lisans Tezi, 104 sayfa.

[75] Karademir A., Varlıbaş H., Çiçek M (2013). "Kağıt üretiminde $\mathrm{CaCO} 3$ dolgu maddesinin kimyasal tutunması üzerine bir araştırma”. SDÜ Orman Fakültesi Dergisi 14, 48-52.

[76] Sabah E., Erkan Z.E (2014). "Türkiye kağıt üretim teknolojisini değiştiren mineral: Kalsiyum Karbonat (CaC03)”. V. Endüstriyel Hammaddeler Sempozyumu, 13-14 Mayıs 2004, İzmir, 101-109.

[77] Tozsin G., Oztas T., Arol A.I., Kalkan E., Duyar O (2014). "The effects of marble wastes on soil properties and hazelnut yield". Journal of Cleaner Production 81, 146-149.

[78] Marras G., Bortolussi A., Peretti R., Careddu N (2017). "Charecterization methodology for re-using marble slurry in industrial applications". Energy Procedia 125, 656-665.

[79] Aruntaş H.Y., Guru M., Dayı M., Tekin I (2010). "Utilization of waste marble dust as an additive in cement production". Materials and Design 31, 4039-4042.

[80] Sağlam G (2012). "Çimento üretiminde atık mermer tozu ve atık alçının kullanılabilirliği”. Yüksek Lisans Tezi, Gazi Üniversitesi Fen Bilimleri Enstitüsü, Ankara, 94 sayfa.4

[81] Shah W., Nafees M., Iqbal M (2015). "Evaluation of marble slurry waste for preparation of commercial grade cement". Journal of Engineering and Applied Science 34(1), 1-10.

[82] Shah W., Nafees M (2016). "Marble waste: A Problem or a resource?". II. International Conference on Sustainable Utilization of Natural Resources, Poster.

[83] Sabah E., Çelik M.Y (2001). "İscehisar (Afyon) mermer atıklarının hayvan yemi katk1 maddesi olarak kullanılabilirliğinin araştırılması". Türkiye III. Mermer Sempozyumu, 3-5 Mayıs 2001, Afyon, 309-316. 